\title{
Poor Institutions, Rich Mines: Resource Curse in the Origins of the Sicilian Mafia (short title: INSTITUTIONS, MINES AND SICILIAN MAFIA)*
}

\author{
Paolo Buonanno, Ruben Durante, Giovanni Prarolo and Paolo Vanin
}

\begin{abstract}
With weak law-enforcement institutions, a positive shock to the value of natural resources may increase demand for private protection and opportunities for rent appropriation through extortion, favoring the emergence of mafia-type organizations. We test this hypothesis by investigating the emergence of the mafia in XIX century Sicily, where a severe lack of state property-right enforcement coincided with a steep rise in international demand for sulfur, Sicily's most valuable export commodity. Using historical data on the early incidence of mafia activity and on the distribution of sulfur reserves, we document that the mafia was more present in municipalities with greater sulfur availability.
\end{abstract}

\footnotetext{
${ }^{*}$ Corresponding author: Giovanni Prarolo, Department of Economics, University of Bologna, Piazza Scaravilli 2, 40125 Bologna, Italy. Email: giovanni.prarolo@unibo.it.

We are grateful to the editor Stephen Machin and an anonymous referee for her remarks. We also thank Francesco Amodio, Oriana Bandiera, Giorgio Chiovelli, Francesco Cinnirella, Carl-Johan Dalgaard, Alfredo Del Monte, Arcangelo Dimico, Giovanni Federico, Oded Galor, Diego Gambetta, Paola Giuliano, Luigi Guiso, Nathan Nunn, Paolo Pinotti, Nancy Qian, Mathias Thoenig, David Weil, and one anonymous referee for helpful comments. We also thank participants in the Transatlantic Workshop on the Economics of Crime, the Frontier Research in Economic and Social History Meeting, the CEPR-EIEF Conference on Economics of Interactions and Culture, the Conference on Intergenerational Transmission of Entrepreneurship, Occupations and Cultural Traits in the Process of Long-run Economic Growth, the SIE Conference, the 2013 annual Conference of the Royal Economic Society and the 2013 NBER Summer Institute and seminar participants at DIW, Collegio Carlo Alberto, University of Barcelona, University of Bologna, University of Neuchatel, Free University of Berlin and University of San Andrés, PUC Rio de Janeiro, and University of Milan for helpful discussion. All errors are our own. All necessary data sets and programs to replicate results are available online.
} 
In 1883 Sicily was shaken by the discovery, in the heart of its sulfur-producing area, of the first documented mafia-type criminal organization, the Brotherhood of Favara (Dickie, 2004). More than 200 affiliates (on a total of above 500) were arrested; 107 of them were convicted in the following trial. Of these 107, 72 were workers, at different layers, of the sulfur industry. We document in this paper that this episode was not just a curiosum: there is a systematic causal link from sulfur availability to mafia's emergence (and persistence) in Sicilian municipalities. We argue that this reflects a broader phenomenon, namely the fact that under weak institutions an increase in the value of lootable natural resources may foster mafia-type organizations.

A large literature in economics and political science has investigated the effect of natural resources on political and economic development (Sachs and Warner, 1995, 2001; Mehlum et al., 2006a,b; Voth and Drelichman, 2008; Haber and Menaldo, 2011). These studies have delivered rather mixed results, and a general consensus has not emerged on whether, ultimately, resource abundance should be viewed as a "blessing" or as a "curse". 1 But what factors explain why the discovery of valuable resources can lead to desirable outcomes in some countries (e.g. Norway, Australia) and to deleterious ones in others (e.g. Nigeria, Zimbabwe)? The quality of pre-existing political and legal institutions is arguably important: when institutions are dysfunctional, conflict over access to resource rents is likely to escalate, giving rise to increased corruption, rent-seeking, and even violence (Skaperdas, 2002; Collier and Hoeffler, 2002), and resources may be diverted from human capital accumulation and other productive uses (Cabrales and Hauk, 2011; Dal Bó and Dal Bó, 2011; Dube and Vargas, 2013). Similarly, the literature on organised crime (Gambetta, 1993; Konrad and Skaperdas, 2012) has argued that the combination of weak institutions and resource abundance can be conducive to the emergence of mafia-type organizations, which can have profound and long-lasting effects on a country's economic prospects.

The socio-economic consequences of organised crime have been a subject of growing interest among academics and policy-makers alike (Jennings, 1984; Fiorentini and Peltzman, 1997; Skaperdas, 2001). Research on the topic has focused, in particular, on the study of mafia-type

\footnotetext{
${ }^{1}$ See Frankel (2010) for a comprehensive survey on the topic.
} 
organizations operating in various parts of the world. ${ }^{2}$ While these contributions have expanded our knowledge of the nature and structure of such organizations, their economic origins remain largely unexplored.

Our paper attempts to fill this gap advancing the hypothesis that, when public law-enforcement institutions are weak or absent, a boom in the value of natural resources significantly contributes to the emergence of mafias, because it creates both a demand for private protection and opportunities to extract rents through extortion, two dimensions along which mafia-type organizations have a competitive advantage, thanks to the coordinated use (or threat) of violence (indeed, protection and extortion are often hard to disentangle, and they appear as the two sides of the mafia coin). While this argument can potentially be applied to a variety of mafia-type organizations around the world, we empirically test it for the specific case of the Sicilian mafia, the oldest and most notorious mafia, which dates back to the XIX century and which has had a considerable and long-lasting effect on Sicily's socio-economic development. ${ }^{3}$

After the demise of feudalism and the collapse of the Bourbon Kingdom, Sicily was characterised by a severe and widespread lack of state enforcement of law, which was even more pronounced in sulfur mines than elsewhere. At the same time, the value of its sulfur reserves boomed, due to a sharp increase in sulfur demand from industrialised countries. Due to abundant and superficial availability, Sicilian sulfur extraction correspondingly rose, up to the point that, by the end of the XIX century, Sicily was covering more than $80 \%$ of the world sulfur market. Since the actual shock to the value of natural resources depended on sulfur presence, we exploit the exogenous distribution of sulfur reserves across Sicilian municipalities to identify how such shock contributed to mafia's emergence. As it will be clear throughout the rest of the paper, we do not claim that sulfur was the sole cause of the emergence of Sicilian mafia. What we indeed claim is that the effect of sulfur on the emergence of mafia is the only one (i) clearly

\footnotetext{
${ }^{2}$ Relevant contributions on mafia-type organizations by sociologists include Gambetta's seminal work on the Sicilian mafia (1993), Varese's studies of the Russian mafia (2005), and of the Japanese Yacuza. Recent contributions by economists have looked the economic impact of the Sicilian mafia (Pinotti, forthcoming) and the workings of criminal networks in the context of the American mafia (Mastrobuoni and Patacchini, 2012).

${ }^{3}$ Lupo (1993) and Dickie (2004) provide an excellent account of the history of the Sicilian mafia and of its expansion to other regions of Italy and to the United States.
} 
identifiable and (ii) empirically robust.

While documenting the magnitude of the shock and defending the exogeneity of its distribution is relatively straightforward, establishing that municipalities that experienced such a shock were ex-ante similar to those that did not is a more demanding task. One crucial difficulty lies in excluding that differences in the availability of natural resources are correlated to differences in other dimensions (e.g. institutional quality), which may affect mafia's emergence through other channels. To address this concern, we pursue several strategies. First, we document that differences in sulfur reserves are not correlated with population growth rates in previous centuries. Since in the context of a Malthusian regime population represents a good indicator of the degree of economic development, this is indicative of the fact that sulfur played no special economic role prior to the XIX century. Second, in our econometric analysis we control for a wide range of observables that are likely to be correlated with institutional quality, economic activity and geographic and demographic differences. Indeed, we employ a comprehensive dataset, which combines various measures of early mafia's diffusion across Sicilian municipalities with detailed information on natural resource endowments and a range of other geographical and socio-demographic characteristics. Third, in all our specifications we include area fixed effects, which allows us to identify our main effect from variations in sulfur endowment within small areas, which are plausibly homogeneous along several non-observable dimensions. Fourth, to account for possible spatial correlation in mafia's emergence, we replicate our analysis using spatial regression methods. Finally, following Acemoglu et al. (2012), we perform additional tests of our hypothesis based on the comparison of pairs of neighbouring municipalities with different sulfur endowment. ${ }^{4}$

Our empirical findings provide strong support for our main hypothesis. In particular, we find that sulfur availability has a positive and significant effect on early incidence of mafia activity. Our findings are robust to the use of different measures of early mafia incidence, to the introduction of a number of geographical and socio-economic controls, and to the use of the

\footnotetext{
${ }^{4}$ Acemoglu et al. (2012) employ this strategy to estimate the effect of gold-mines-related slavery in Colombia. One advantage of our application is that we do not have to worry about the endogeneity of slavery, since we are directly interested in the effect of natural resources.
} 
complementary approaches discussed above. We also discuss and test alternative explanations of the emergence of the Sicilian mafia proposed in the literature which, however, do not appear to find strong support in the data. In addition, none of the alternative explanations we test are clearly identifiable, so that we can spot, at most, correlations among early mafia emergence and these supposed explanations. Although the focus of our analysis is on mafia's emergence, in the last part of the paper we also document the existence of a strong correlation between historical and current mafia presence, and discuss the possibility of using historical sulfur availability as an instrument for the latter.

Although specific to the case of the Sicilian mafia, we believe that our findings can be helpful to inform our understanding of the rise of mafia-type organizations in various different parts of the world, where similar economic and institutional conditions may have occurred. ${ }^{5}$

The remainder of the paper is organised as follows. Section 1 illustrates our theoretical framework and relates our work to the literature on mafia-type organizations and resource curse. In section 2 we discuss the socio-economic and political conditions of XIX century Sicily that favored mafia's emergence, with particular regard to the collapse of the Bourbon regime and the upsurge in sulfur's value. In section 3 we present the data used in the empirical analysis, while in section 4 we describe our empirical strategy and discuss our findings. Section 5 concludes.

\section{On Mafia and Resource Curse}

Our research first relates to the vast literature on the socio-political impact of natural resources. This literature has discussed various mechanisms through which resource abundance may ultimately be regarded as a "curse": vast resources may fuel violence, theft and looting (Skaperdas, 2002), they may be used to finance rebel groups, warlords or civil wars (Collier and Hoeffler, 2002), or may favor the emergence of criminal organizations aiming to extract part of the wealth derived from their exploitation. Although some evidence suggests that resource-rich countries

\footnotetext{
${ }^{5}$ It is the case, for example, of Yakuza in Japan, the Triad in Hong Kong and the Russian mafia. Indeed, Yakuza had its origins after the demise of the feudal system in Japan, while the Russian mafia after the dissolution of the USSR.
} 
display worse economic performance than resource-poor ones (Sachs and Warner, 1995, 2001), no unanimous consensus on this matter has emerged (see for example Haber and Menaldo, 2011). In fact, as some observers have pointed out, whether natural resources may result in a "curse" or a "blessing" may crucially depend on a country's institutional quality (Mehlum et al., 2006a,b; Cabrales and Hauk, 2011). ${ }^{6}$ In the presence of weak institutions, our argument goes, natural resources are particularly vulnerable to predatory attacks; in this context, the (illegal) use of violence provides mafia-type criminal organizations with a competitive advantage in the supply of protection and extortion (Gambetta, 1993; Konrad and Skaperdas, 2012), resulting in the capacity to extract a substantial portion of natural-resource-based rents. ${ }^{7}$

Our data structure, that exploits within-country variations in natural sources availability, has the advantage of downsizing a plausible effect of natural resources on institutions (a possible confound), since the latter are often designed at national level. Although studies that use this data structure (such as Caselli and Michaels (2013) and Naritomi et al. (2012), both using municipality-level data for Brazil) have to renounce to some degree of external validity, the possibility to pin down the existing institutional framework is of great importance.

This research integrates two previous econometric studies that have looked at the historical emergence of the Sicilian mafia. The first one, by Bandiera (2003), uses a common agency model to formalise the idea that the mafia should have been historically more active in towns were land was more fragmented, and finds support for this hypothesis using qualitative data from an 1885 parliamentary survey (Damiani, 1885) on 70 districts (mandamenti) in western Sicily. ${ }^{8}$ The second one, by Pazzona (2010), expands Bandiera's sample to 160 observations,

\footnotetext{
${ }^{6}$ Institutional quality may, in turn, depends on features as diverse as geographic isolation, ethnic divisions, or state collapse (Skaperdas, 2011).

${ }^{7}$ Dal Bó and Dal Bó (2011) emphasise different factor intensities to explain why price shocks to different commodities have different effects on social conflict. Dube and Vargas (2013) show evidence that in Colombia price increases in agricultural product and in natural resources are associated to a decrease and to an increase in violence, respectivey, because the former raise the opportunity cost of violence and the latter raise the incentive to appropriate rents through violence. Yet notice that in XIX century Sicily both agriculture and extraction of natural resources were labour intensive.

${ }^{8}$ The argument is based on the idea that the purchase of protection by a single landowner imposes a negative externality on the other ones (since it deflects thieves on their properties), and that, hence, landlords will be competing with each other to acquire protection and to exclude others from it. By increasing the number of competing landlords, land fragmentation should increase mafia's potential profits. We present and discuss in detail in the data section the parliamentary survey employed by Bandiera (2003) and the administrative jurisdictions in XIX century
} 
documenting that the mafia was more likely to emerge where the competition by new social actors was harsher, particularly in areas where land value was higher and land holdings larger, at the opposite of what Bandiera (2003) finds. We improve upon these contributions by expanding the scope of the analysis to a much larger and more detailed set of geographical units covering the entire island; this allows us to investigate the large differences in mafia incidence across Sicilian areas, which is considered one of the most puzzling questions about the history of the Sicilian mafia. ${ }^{9}$

More in general, the results of this research complement the literature on the emergence of persistent social institutions as the consequence of what can be viewed as a 'historical accident' (Acemoglu et al., 2001), which in the context our our study would be represented by the sudden rise in international demand for Sicilian sulfur. Although geographical characteristics per se are not the focus of our study, the findings we present can also be interpreted in the context of the debate on the long-term impact of geography on socio-economic development. Previous research has documented that the environment can influence economic performance directly, through its effect on health and agricultural productivity (Landes, 1998; Sachs and Malaney, 2002), and indirectly, by setting the conditions in which social norms and political institutions have formed (Sokoloff and Engerman, 2000; Easterly and Levine, 2003; Durante, 2009; Nunn and Puga, 2012; Michalopoulos et al., 2012) or by defining environmental constraints to population growth (Galor and Weil, 2000). The evidence presented here suggests that, under given economic circumstances, geographic characteristics may have contributed to the emergence of particular forms of social organizations (criminal ones in this case), which have persisted over time and continue to have relevant socio-economic effects.

${ }^{9}$ This aspect has been discussed by historians, sociologists and economists alike. Some examples include Lupo (1993); Gambetta (1993) and Sylos Labini (2003).
} 


\section{Historical Background}

XIX century Sicily presented the two conditions that, according to the "resource curse" argument discussed above, are conducive to mafia's emergence: poor quality of law-enforcement institutions and soaring value of domestic natural resources. In what follows we discuss some aspects of the XIX century Sicily political and socio-economic context that are relevant to our analysis, with particular regard to the main sources of institutional weakness, and the impact of growing international demand for Sicily's high-value mining production.

\subsection{Institutional Weakness and Economic Development}

Two major political transformations characterised the history of Sicily during the XIX century: the demise of feudalism in 1812, and the collapse of the Bourbon's domination in 1861. Both these events contributed to the disruption of Sicilian law enforcement institutions and the deterioration of property-rights security.

Feudal barons had long been struggling with the monarchy, which imposed on them a heavy fiscal burden, and this struggle intensified when, in 1806, in an attempt to escape from the French, the Bourbons moved from Naples to Palermo, Sicily's capital. At the beginning of the XIX century most of Sicilian municipalities were under barons' direct jurisdiction; however, most feudal lords did not reside in their lands but in Palermo, the centre of the island's political, economic and social life. ${ }^{10}$ Their lands, together with their feudal rights, were generally rented out to local administrators (gabelloti), who were in charge of managing the landholding's productive activities and who invested their own capital in it. The abolition of feudalism represented a profound institutional change, which officially transferred all feudal jurisdictions to the State. Yet, while barons' control over their lands had been weakened, limits to the power of the monarch had also been imposed by the establishment of a parliamentary system that assigned to the Parliament - largely dominated by the barons - extensive powers of control over the King's

\footnotetext{
${ }^{10}$ The port of Palermo was by far the more trafficked in the Island. In 1838, on a total of 480 Sicilian merchant vessels that left for foreign ports, 240 were from Palermo, while only 65 from Messina, the second port in order of importance (Petino, 1958).
} 
acts (Candeloro, 1956). The power struggle between landlords and the Bourbons continued until 1861, when the kingdom collapsed and its territories were annexed to the newly formed Italian State. This institutional struggle resulted in extremely low levels of law enforcement, a situation which did not improve under the unified State.

The feudal economy was primarily agrarian, based on extensive cultivations (mainly cereals) and characterised by very low productivity and peasants' extreme poverty. The abolition of feudalism had little de facto impact on land distribution and did not result in increased productivity (Blok, 1966, 1969). The most valuable productions were particularly exposed to predatory attacks from local bandits (briganti), and the lack of law enforcement by the State triggered the demand for private forms of protection.

Individuals specialised in the use of violence were abundant throughout Sicily. An increase in the demand for private protection could thus be easily met by potential suppliers, who had no difficulty in acquiring information and reputation, the key assets for private protection. In the countryside, gabelloti were surrounded by a number of guards, former soldiers and former convicts, all trained in the use of violence, who, formerly employed by feudal lords, were now looking for new job opportunities. Local networks of such individuals quickly emerged: extremely well informed about the local context - about potential victims of violent predation and potential perpetrators alike - they were in the position to establish a credible reputation as effective protectors. In the words of Franchetti and Sonnino (1877), this process led to a "democratization of violence". As the violent threats used to protect their "clients" could also be used to intimidate them, early mafiosi were in a position to create their own demand; as a consequence, the distinction between supply of protection and threat of extortion was generally unclear. Indeed, various forms of agreements linked briganti and mafiosi, as the latter used the threat of the former to justify the services they offered. ${ }^{11}$

\footnotetext{
${ }^{11}$ Moreover, private protection exerts negative externalities on those who are not protected, since it deflects the threats toward them, as in Bandiera (2003). This is another way in which supply creates its own demand. Del Monte and Pennacchio (2011) show that there was a negative correlation between the intensity of brigandage and that of organised crime after the Italian Unification.
} 


\subsection{Sulfur}

The case of the sulfur industry represents one of the clearest examples of how, in the absence of effective public law-enforcement institutions, a florid market for private protection emerged. Sulfur mines were usually rented out employing gabelloti, as it happened in agrarian estates. Again, this was done to secure the right to exploit sulfur mines under the threat of violent attacks. Even if the kind of property and lending structure of sulfur mines was common to that of other productive assets, there are some specificities pertaining to the mining sector that lead to hypothesise that the mining working environment was particularly conducive to violence. The absence of law enforcement, which characterised Sicily in the XIX century, was exacerbated in the underground life of sulfur caves, with controversies between workers usually solved using violence or its threat: a set of laws regulating within-mines penal responsibilities was approved only in 1893. Due to the lack of organised law enforcement, each miner had to protect his extraction from other miners, as raw material extracted by miners was usually paid only once a week and the material extracted each day was two or three times worth the daily wage of a worker. For the protection of their material, miners were supported by carusi, 10-15 year old boys who helped workers move extracted material and who, in this lawless environment, developed the specific characteristics of a mafioso: use of violence, non-cooperation with others, code of silence, etc. ${ }^{12}$

Once extracted, sulfur minerals - largely produced for export purposes - had to be transported to Palermo or other ports, so cargoes' safety along the way had to be ensured as well. Starting in the first decades of the XIX century, international demand for sulfur soared, as this represented a fundamental intermediary input for industrial and chemical productions, which were quickly expanding both in Britain and France. ${ }^{13}$ For all of the XIX century and during the

\footnotetext{
${ }^{12}$ Since in the empirical part we find strong evidence of sulfur presence as predictor of mafia, as opposed to no effects of citrus cultivation, which shares similar commercialization characteristics, we speculate that the real driver of mafia's emergence was the underground part of the story.

${ }^{13}$ In 1855 over $70 \%$ of Sicilian sulfur was exported to France and Great Britain (Squarzina, 1963). Sulfur is the base of oil of vitriol, and of almost all the acids and alkalis which are extensively used in various manufacturing processes. It is also required for the manufacture of gunpowder as well as for the production of various medicines (Rawson, 1840). Even if industrial substitutes for sulfur have been discovered and developed since the late 1840s, the use of sulfur gained again momentum because of its use in grape cultivation as a fungicide. Still in 1940 sulfur
} 
first decade of the XX century, Sicily represented the world's largest sulfur producer, accounting for up to $83 \%$ of world sulfur production in $1893 .{ }^{14}$

The increase in international demand for sulfur determined an increase in the value of its protection, favoring mafia's emergence. As shown by the case of the Brotherhood of Favara mentioned in the Introduction, protection was not just delegated to carusi, but organised groups soon emerged and started to fight to control the market for sulfur protection, which after decades of growing demand had become highly profitable (indeed, the convicted affiliates to the Brotherhood of Favara belonged to two rival factions, which tried to consolidate their power in the market for sulfur protection).

To identify the effect of the increase in the value of sulfur endowments on mafia's emergence, our empirical analysis exploits exogenous variations in the availability of sulfur across Sicilian municipalities. It is worth to stress that Sicilian sulfur was mainly superficial (Squarzina, 1963; Cancila, 1995) and hence no considerable investments were required to find and extract it, so the information on the presence of sulfur mines proxies very well the presence of sulfur itself. Key to our identification strategy is the assumption that the presence of sulfur reserves was unimportant for local economic activity prior to the XIX century. Available evidence on Sicily's sulfur export is consistent with this view: as shown in figure 1 Sicilian sulfur exports, virtually negligible at the beginning of the XIX century, reached almost 500 thousands tons by the beginning of the XX, accounting for about 4\% of Sicilian GDP. Export growth was especially marked during the years comprised between the 1830 s and the 1850 s when it reached an astonishing 9\% annual rate. ${ }^{15}$ According to Kutney (2009), sulfur in 1852 was the top export from Sicily $(392,000$ British Pounds) before citrus fruits $(362,000)$, olive oil $(163,000)$ and wine (106,000). Using information from Dimico et al. (2012), we obtain that in 1900 the value of export of Sicilian sulfur was at least three times the value of all exported Italian citrus, testifying accounted for $20 \%$ of Sicily's total export value (Pescosolido, 2010).

${ }^{14}$ Sicilian sulfur production and export almost coincided since, throughout the XIX century, virtually no sulfurintensive industries were active in the region, letting aside its use in grape cultivation.

${ }^{15} \mathrm{We}$ focus on export volumes because, around the 1830 s, prices experienced considerable fluctuations due to the establishment and the subsequent dissolution of a monopoly (they remained relatively stable afterwards). The price was fluctuating also in the 1860-1900, according to Squarzina (1963). It went from 120 liras in 1860 to a peak of 142 in 1874, then dropped to 65 in 1889 and recovered to 92 in 1900. 
a consolidated primacy of sulfur export on other commodities throughout all XIX century. ${ }^{16}$ All these factors contributed to increase sulfur producers' demand for protection both around the mines and possibly along the routes connecting them to the main ports.

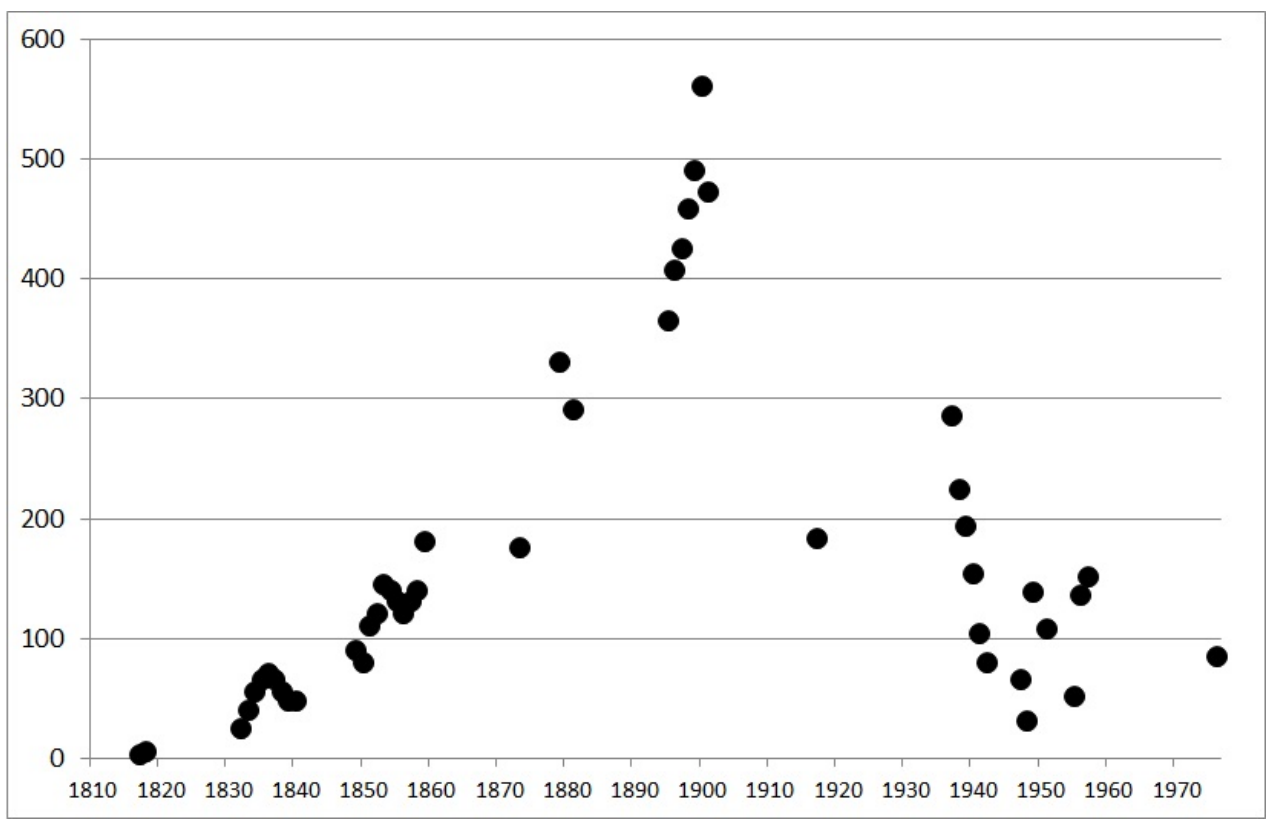

Fig. 1: Export of Sicilian Sulfur

Notes. Thousands of tons of sulfur exported from Sicily. Sources: Squarzina (1963), Cancila (1995) and various entries of Treccani Encyclopedia.

It is important to mention that the export of Sicilian sulfur rapidly declined over the first part of the XX century; this was mainly due to the development of new extraction technologies, which made it cheaper to exploit previously untapped deep reserves in other parts of the world, thus reducing the comparative advantage of Sicilian superficial sulfur mines.

\section{Data}

To test the main predictions of our theoretical argument, we look at differences across Sicilian municipalities. To do so, we use historical data on the presence of the mafia and on the avail-

\footnotetext{
${ }^{16}$ Dimico et al. (2012) report that Italian lemon exports amounted to around 3M \$ in 1900. Sulfur price was around 92 liras and Sicilian exports peaked at $560 \mathrm{~K}$ tons, that at an exchange rate of 5.5 liras per dollar amounts to $9.4 \mathrm{M} \$$.
} 
ability of sulfur in the late XIX century, as well as data on a wide range of geographical and historical controls. In what follows we describe the data sources and discuss how the variables used in the empirical analysis are constructed.

\subsection{Mafia}

Our primary source of data on the early diffusion of the mafia in Sicily is represented by the work of Cutrera (1900). Former law-enforcement official and one of the major experts of the phenomenon of the time, Cutrera collected detailed information on the intensity of mafia activity in 285 Sicilian municipalities in the last decades of the XIX century. In particular, for each municipality, Cutrera assessed the intensity of mafia activity on a four-point scale ranging from none, to low, intermediate and high. Cutrera's data have been extensively used in previous historical and sociological studies on the Sicilian mafia, including Gambetta's seminal contribution (1993). An alternative source of information on the early incidence of mafia activity is represented by the Damiani-Jacini parliamentary enquiry (Damiani, 1885). ${ }^{17}$ This was part of a nation-wide inquiry conducted between 1881 and 1885 with the primary aim of collecting information on the conditions of the peasantry under the newly unified state. ${ }^{18}$ In addition to extensive municipal-level information on a variety of agriculture-related variables, the Damiani-Jacini inquiry contains information on the intensity of mafia activity in 158 Sicilian districts (mandamenti). ${ }^{19}$ This information was collected through a questionnaire transmitted to lower court magistrates (pretori), who were asked to assess the intensity of the activity of the mafia in their district of jurisdiction on a four-point scale analogous to the one used by

\footnotetext{
${ }^{17}$ An additional source is the Borsani-Bonfadini parliamentary enquiry on the conditions of Sicily conducted between 1874 and 1876 . However, this inquiry only reports the 43 municipalities (out of 357) in which the mafia appears to be more widespread. Given its limited scope, we do not use these data in our empirical analysis.

${ }^{18}$ The inquiry started in 1881 and was completed at the end of 1884. The main questionnaire on the conditions of the agrarian class was transmitted to all Sicilian mayors on May $20^{\text {th }} 1883$. A complete version of the questionnaire can be found at page V, volume XIII, tome II, fascicle IV of the official inquiry report.

${ }^{19}$ Post-unification Sicily was characterised by four levels of administrative division: the largest was the province, followed by the department (circondario), the district (mandamento), and the municipality (comune). Overall, Sicily was divided into 7 provinces (Caltanissetta, Catania, Girgenti, Messina, Noto, Palermo, Trapani), 24 departments, 179 districts and 357 municipalities.
} 


\section{Cutrera. ${ }^{20}$}

We believe that Cutrera's data are preferable to Damiani-Jacini's for several reasons. First, unlike Damiani-Jacini's, Cutrera's data are available at the municipal level and cover the large majority of Sicilian municipalities (about 80\%), allowing for a more extensive and finer empirical assessment of the relationship between sulfur availability and early mafia activity. One important drawback of the Damiani-Jacini's data is that the reported level of mafia activity is solely based on the subjective assessment of respondents and is therefore susceptible to differences in the evaluation criteria adopted by local officials. Actual unawareness, fear of retaliation or contiguity with the mafia would, for example, bias respondents towards underreporting the level of mafia activity in their jurisdiction, introducing a measurement error. As discussed in Pazzona (2010), the problem would be even more severe if such factors were themselves correlated to actual mafia activity (or to its determinants). Cutrera's measure is likely to be less vulnerable to this concern. On the one hand, there is no reason to believe Cutrera would employ different evaluation criteria when assessing the level of mafia activity in different municipalities. On the other hand, given his position of outside observer, it is reasonable to think that Cutrera's assessment of mafia activity would be relatively unresponsive to the specific incentives faced by local officials (and, indirectly, to the actual strength of mafia activity). We therefore believe that the use of Cutrera's measure would mitigate the empirical problems discussed above, although we do not claim that it eliminates them. Although our empirical analysis will primarily rely on Cutrera's data, we will also test the robustness of our findings using the Damiani-Jacini's district-level data. In what follows, we indicate with $m a f_{-} c$ and $m a f_{-} d$, the index of mafia intensity based respectively on Cutrera and Damiani-Jacini.

The geographical distribution of the Sicilian mafia in the late XIX century, based respec-

\footnotetext{
${ }^{20}$ The jurisdiction of low court magistrates coincided with the district; hence their assessment of the activity of the mafia reported in the Damiani-Jacini inquiry has to be understood as referring to the entire district area, and not just to one or more municipalities within the district. This aspect has generated some confusion among users of the Damiani-Jacini's data (Bandiera, 2003; Pazzona, 2010; Dimico et al., 2012), who appear to have erroneously interpreted the information on the activity of the mafia as referring to the municipal rather than the district level. This confusion can probably be attributed to the presence, in most districts, of municipalities with the same name as the district they are part of (e.g. municipality of Messina in the district of Messina, municipality of Girgenti in the district of Girgenti, etc.).
} 
tively on Cutrera's and Damiani-Jacini's data, is depicted in Figure 2. Relative to DamianiJacini, Cutrera's data indicates that the mafia was more present in the Western part of the island, particularly in the areas around Palermo and Agrigento. This pattern, largely consistent with numerous reports from historians and early mafia experts (see Lupo, 1993 and Sylos Labini, 2003 among others), is further reassuring on the accuracy of Cutrera's data.

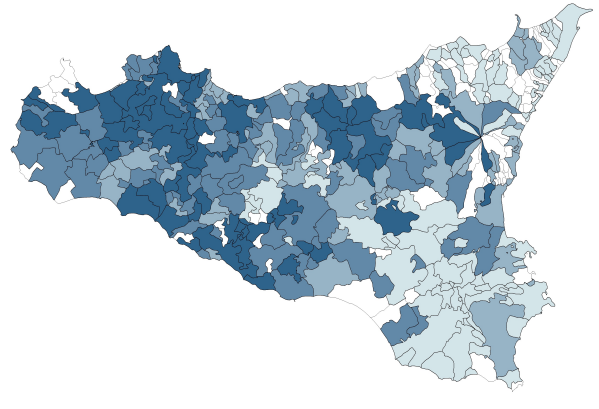

(a) Cutrera

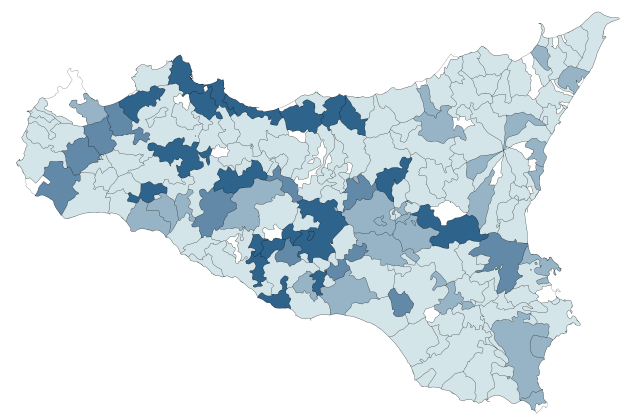

(b) Damiani-Jacini

Fig. 2: Geographic Distribution of the Sicilian Mafia in the Late XIX Century

\begin{abstract}
Notes. The figure reports the assessment of the intensity of mafia activity according to Cutrera (left) and Damiani-Jacini (right), with darker greys indicating more intense mafia's activity (missing values are reported in white). Cutrera's data are at the municipality level while Damiani-Jacini's are at the district level. Missing values correspond to cases for which it was not possible to match historical municipalities (or districts) to current ones, e.g. for municipalities created in the $\mathrm{XX}$ century.
\end{abstract}

\title{
3.2. Sulfur and Other Geographical and Historical Variables
}

With regard to the presence of sulfur, comprehensive municipal data are available from Squarzina (1963). These include information on the number of sulfur mines in each Sicilian municipality in 1886 - that is, around the peak of Sicily's sulfur export boom. Since we are interested in gauging the original stock of sulphur available in each municipality - hence prior to the intense depletion which took place throughout the XIX century - we consider both mines that were still operating in 1886 as well as those that were already exhausted by then. It is worth emphasizing, once again, that Sicilian sulfur was generally superficial so that its extraction was relatively unchallenging and did not require considerable investments; as a consequence, at the 
peak of Sicily's sulfur export boom, virtually all major sulfur reserves on the island had been tapped (Squarzina, 1963). In light of this fact, the presence of sulfur mines can be considered a good proxy for the exogenous distribution of sulfur reserves, which is ultimately our variable of interest. Our key explanatory variable is the number of sulfur mines in each municipality (labelled sulfur henceforth), that is summarised in Figure 3.

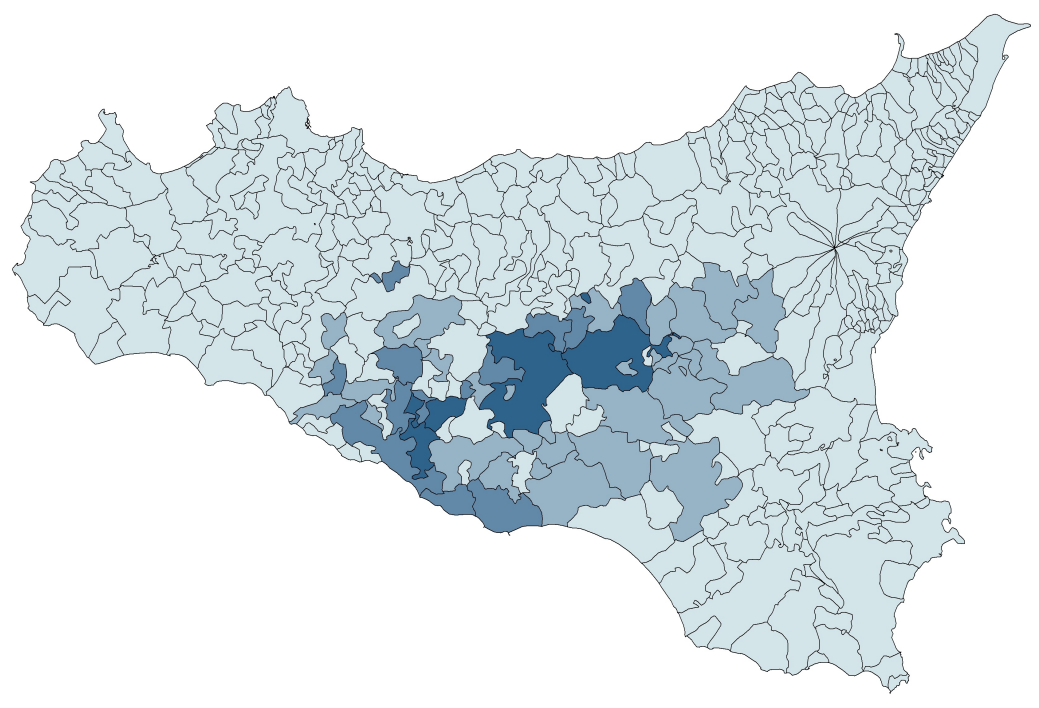

Fig. 3: Geographic Distribution of Sicilian Sulfur Mines (1886)

Notes. The figure reports the number of sulfur mines (both active and exhausted) recorded in each Sicilian municipality in 1886 on a four-level scale: 0 (lighter gray), 1-10, 11-30, more than 30 (darker gray).

In our empirical analysis we control for a range of other geographical and historical variables at the municipal level. We focus, in particular, on factors that may have influenced the demand and supply of mafia services and, at the same time, may be correlated with the presence of sulfur, in order to be sure that our variable of interest reflects the effect of sulfur availability on mafia's emergence and is not merely proxying for other characteristics.

To account for differences in topography, we control for terrain ruggedness and elevation. As discussed by Nunn and Puga (2012), in addition to its obvious effect on agricultural productivity and trade, rugged terrain - in the form of hills, caves and cliffs - provides lookout posts 
and hiding places for individuals trying to escape. Arguably, in the context of Sicily rugged areas provided outlaws with better protection from police forces. This view is consistent with accounts by various historians; for example, when discussing the widespread presence of the mafia in the mountainous towns of Gangi, Lupo (1993) emphasises the importance of the town's impervious location, which made it particularly difficult for law enforcement officers to establish control over the surrounding area and apprehend criminals. To account for this aspect, we include in our regressions a municipal measure of terrain ruggedness constructed from the Global Land One-km Base Elevation Project (GLOBE), a global gridded digital elevation data set covering the Earth's surface at a 10-minute spatial resolution (approximately $1 \mathrm{~km}$ ). ${ }^{21} \mathrm{Re}$ latedly, we also control for difference in elevation within a given area, a variable which has been identified in the literature as imposing significant limitations on both agriculture and breeding activities (Michalopoulos, 2012; Grigg, 1995; Lupo, 1993). In particular, we use data on the maximum difference in altitude in a given municipality available from the Italian Institute of Statistics (ISTAT).

We are also interested in controlling for the suitability of local land for various types of crops, as this is likely to have affected the demand for protection of agricultural goods. In fact, while some low-value crops (i.e. cereals) were consumed locally, others (e.g. citrus fruits, olive, sumac) were high-value export goods which might demand a degree of protection similar to that of sulfur. To account for this aspect, we include in our regressions measures of land suitability for the three most widespread crop categories in XIX century Sicily: i) citrus fruits, ii) cereals, and iii) olives. These measures are constructed using data on crop-specific agro-ecological suitability available from the IIASA-FAO Global Agro-Ecological Zones project (GAEZ). ${ }^{22}$ The GAEZ data are in grid format, have a very high resolution (1'), and assign to each grid cell a value from 0 (totally unsuitable), to 100 (very suitable). To obtain suitability measures at the municipality level we average the individual suitability score of all the cells in a given munici-

\footnotetext{
${ }^{21}$ The GLOBE data set has superseded the GTOP30 which, before the introduction of GLOBE, was considered the most accurate digital elevation data set and had been used, among others, by Nunn and Puga (2012).

${ }^{22}$ More information on the FAO-GAEZ project can be found at http://www.gaez.iiasa.ac.at/. Data from FAOGAEZ have been used extensively by economists in recent years to investigate a variety of topics. Examples include Nunn and Qian (2011), Michalopoulos (2012) and Durante (2009).
} 
pality. We focus on crop suitability - determined in large part by exogenous soil properties and climatic conditions - rather than on actual crop production to minimise concerns of possible reverse effects of mafia's presence on the prevalence of particular crops. ${ }^{23}$ Given the importance of irrigation for several of the crops mentioned above, and in light of the accounts of various observers about the crucial role played by the mafia in controlling water supply, we also control for the relative scarcity of water in a given area using data on the presence of underground water basins available from the Sicilian Waters Observatory.

Another set of controls is intended to capture factors such as access to major ways of communication and proximity to the main ports, which were arguably important determinants of the value of protection. The first variable, labelled as postal roads, indicates whether, at the beginning of the XIX century, a municipality had direct access to one of the postal roads which connected Sicily's largest towns. The data are derived from the digitalization and geo-referencing of a detailed historical map of Sicily in late XVIII century (Cary, 1799), hence prior to the steady rise in sulfur's international demand. Other variables include the distance of a municipality's centroid from the closest non-seasonal river (river distance), and distance from the closest commercial port (port distance). ${ }^{24}$

We also control for a set of socio-economic and demographic characteristics, which could potentially be related to both sulphur availability and mafia presence. In particular, to account for the fact that crime incidence might be higher in more densely populated areas (Glaeser et al., 1996; Glaeser and Sacerdote, 1999; Buonanno et al., 2012) we control for a measure of population density (density) based on data on municipal population from the 1861 census. $^{25}$ Relatedly, to control for possible differences between rural and urban areas, we also define a

\footnotetext{
${ }^{23}$ In the Online Appendix, to test one of the alternative hypothesis about mafia's emergence, we use information on the proportion of land devoted to the cultivation of citrus fruits in each municipality, available from the DamianiJacini inquiry.

${ }^{24}$ Sicily's main commercial ports were: Mazara del Vallo, Porto Empedocle, Trapani, Siracusa, Catania, Palermo and Messina.

${ }^{25}$ By 1861 Sicily's total population amounted to 2.1 million, accounting for more than $10 \%$ of Italy's population. Population density was more than 81 inhabitants per squared kilometer, roughly comparable to the current density of Spain. Since then, the increase in population has been rather homogeneous across Sicilian municipalities, resulting in a correlation between population in 2001 and in 1861 of of 0.95 . Palermo, the capital, was Sicily's largest and denser city, with a population of 185,000 inhabitants and a density of 1,000 inhabitants per squared kilometer, comparable to that of current mid-size Italian cities.
} 
dummy variable, urban, indicating whether a municipality is located within a $10 \mathrm{Km}$ distance from one of Sicily's then five largest cities. ${ }^{26}$

Finally, we also control for the degree of land fragmentation, a factor which previous contributions have related to the development of a florid market for private protection and the consequent emergence of the mafia (Bandiera, 2003). Information on the degree of land fragmentation in each municipality is available from one of the questionnaires of the Damiani-Jacini's inquiry, in which mayors where asked to report whether land in their municipality was prevalently composed by small, medium or large landholdings. In particular, we define a dummy variable, fragmentation, taking value one for municipalities where small and medium landholdings were prevalent, and zero in those in which large landholding still existed. Due to the rather low response rate to this question, data on fragmentation are available for only 237 out of the 285 municipalities in our sample.

The availability of data at the municipal level allows us to include in all our regression department fixed effects, which capture the political and historical background common to all municipalities in the same department. In particular, since in the period under examination the Sicilian administrative, judicial and law-enforcement systems were organised at department level, the inclusion of 24 department fixed effects allow us to estimate the effect of sulfur on mafia by comparing municipalities characterised by a fairly homogeneous levels of institutional quality. Descriptive statistics on all variables are reported in Table 1.

\section{Empirical Analysis}

This section presents the empirical assessment of how geographical variations in sulfur endowment contributed to the emergence of the Sicilian mafia. As discussed above, over the XIX century Sicily experienced the collapse of the Bourbon Kingdom and a generalised situation of weak law enforcement. Over the same century, international demand for sulfur soared and most of the world supply came from Sicily. Municipalities with sulfur reserves thus experi-

\footnotetext{
${ }^{26}$ These include: Palermo, Catania, Trapani, Messina and Girgenti.
} 
Table 1: Descriptive Statistics

\begin{tabular}{lccccc}
\hline Variable & Obs. & Mean & Std. Dev. & Min & Max \\
\hline maf_c & 285 & 1.435 & 1.138 & 0 & 3 \\
maf_d & 158 & 0.689 & 1.064 & 0 & 3 \\
Sulfur & 282 & 1.965 & 7.064 & 0 & 61 \\
Sulfur dummy & 282 & 0.165 & 0.373 & 0 & 1 \\
Citrus suitability & 282 & 15.608 & 7.658 & 0 & 48 \\
Cereals suitability & 282 & 17.728 & 11.149 & 1.490 & 66.380 \\
Olive suitability & 282 & 30.906 & 12.065 & 3.478 & 69.273 \\
Water scarcity & 282 & 0.702 & 0.458 & 0 & 1 \\
Ruggedness & 282 & 433.630 & 195.940 & 58.017 & $1,149.332$ \\
Diff. elevation & 282 & 796.837 & 519.126 & 48 & 3,232 \\
Postal roads & 282 & 0.550 & 0.498 & 0 & 1 \\
Distance to river & 282 & 9.279 & 7.247 & 0.992 & 42.075 \\
Distance to port & 282 & 37.924 & 19.371 & 0.132 & 83.919 \\
Urban & 282 & 0.124 & 0.330 & 0 & 1 \\
Population density & 282 & 132.412 & 126.861 & 4.856 & $1,177.986$ \\
Land fragmentation & 237 & 0.759 & 0.428 & 0 & 1 \\
\hline
\end{tabular}

Notes. Descriptive statistics of the main variables used in the empirical analysis. Data is at the municipality level except for $m a f_{-} d$ that is collected at the district level. 
enced a boom in the value of their natural resources. ${ }^{27}$ We exploit the exogenous distribution of sulfur reserves to identify the effects of such boom on mafia's emergence. We document a resource curse, by which valuable natural resources fostered protection demand and extortion opportunities, thus favoring the emergence of organised crime.

As a preliminary check, we present some evidence corroborating the idea that sulfur did not play any relevant economic role before the XIX century, so that any ex-ante differences between sulfur-rich and sulfur-poor municipalities are not driven by sulfur presence. Before 1800, the Sicilian economy was arguably characterised by a Malthusian regime, in which development is meaningfully proxied by population growth. For all municipalities for which we have population data for the XVII and the XVIII century, Table 2 reports OLS regressions of average population growth on initial population (in $\log$ ) and on sulfur. ${ }^{28}$ The three columns refer to population growth in each century and in the whole period, respectively. Sulfur is never significant, confirming its irrelevance for previous economic development. Together with the already documented fact that sulfur exports were negligible at the beginning of the XIX century, this evidence is our first and preliminary step to tackle the issue of ex-ante similarity of municipalities with and without sulfur. In the following analysis, we tackle such issue in many additional ways.

\subsection{Municipality-level Estimates}

Table 3 provides our first clear evidence of the importance of sulfur for mafia's emergence. It reports municipality-level OLS estimates of our preferred mafia measure $\left(m a f_{-} c\right)$ on the number of sulfur mines (sulfur). The different columns gradually increase the number of control variables. ${ }^{29}$ Column 1 shows that, in a univariate regression (including a constant, as all regressions

\footnotetext{
${ }^{27}$ As already shown in figure 1, sulfur export in Sicily grew at an impressive rate of $9 \%$ throughout the period 1830 and 1860 and in that period Sicily served around $90 \%$ of the world sulfur demand. sulfur export was negligible at the beginning of the XIX century, peaked at the end of that century (reaching 540,000 tons in 1901) and sharply declined in the XX century (by 1976, it was only 85,000 tons).

${ }^{28}$ Data for population of Italian towns between 1300 and 1861 are available from Paolo Malanima at: http://www.paolomalanima.it/DEFAULT_files/Page646.htm

${ }^{29}$ Since maf $_{-} \mathrm{c}$ is an ordinal variable, we also estimate an ordered probit model; when doing so we obtain analogous results (available upon request).
} 
Table 2: Growth Regressions

Dependent variable: population growth

\begin{tabular}{lccc}
\hline & $(1)$ & $(2)$ & $(3)$ \\
\cline { 2 - 4 } & $1600-1700$ & $1700-1800$ & $1600-1800$ \\
\hline Ln(population 1600) & $-0.1660^{* * *}$ & & $-0.0900^{* *}$ \\
Ln(population 1700) & $(0.0576)$ & & $(0.0404)$ \\
Sulfur & & -0.0761 & \\
Observations & 0.0003 & $(0.0608)$ & -0.0002 \\
$R^{2}$ & $(0.0030)$ & -0.0002 & $(0.0022)$ \\
\hline
\end{tabular}

Notes. This table presents the results of OLS estimates for Sicilian municipalities for which population was positive in at least two of the years 1600, 1700 or 1800, according to Malanima's data (http://www.paolomalanima.it/DEFAULT_files/Page646.htm). The dependent variable is the yearly population growth while the explanatory variables are the log of population at the beginning of the period and Sulfur, the number of sulfur mines as collected by Squarzina (1963). Robust standard errors are presented in parentheses. *, ** and *** denote rejection of the null hypothesis of the coefficient being equal to 0 at $10 \%, 5 \%$ and $1 \%$ significance level, respectively. 
in all tables), the estimated coefficient on sulfur, significant at the $1 \%$ level, is equal to 0.033 , implying that a one standard deviation increase in sulfur leads to an increase in maf_c by more than one sixth of a standard deviation. ${ }^{30}$ In light of the distribution of maf $c$ and sulfur, this effect appears important in magnitude (although, as one should expect, not huge) and it is highly significant. Moreover, as shown in the rest of this section, it is very robust and stable both in magnitude and in significance. Given the clear identification provided by the exogenous shock in the value of sulfur resources we claim our findings to be causal. Column 2 adds department fixed effects. This is our first step in tackling the issue of whether differences in sulfur endowment pick up differences in other variables, which may matter for mafia's emergence. Such fixed effects control for any characteristics that were common within a department. As previously mentioned, the administration of justice and law enforcement in Sicily were organised at the level of departments, so that these fixed effects are meant to capture heterogeneity also along this dimension. ${ }^{31}$ The result shows that, even within each department, municipality-level variations in sulfur endowment are positively and significantly associated to variations in early mafia's presence (the point estimate is 0.022 and it is again significant at the $1 \%$ level).

To minimise the risk that within-department variations in sulfur endowment are related to differences in other variables, which may themselves be related to mafia activity, columns 3 to 7 progressively add municipality-level controls for differences in agriculture, geography, transportation and communication, socio-demographic variables and land fragmentation (always including department fixed effects). No matter which controls we include, sulfur remains highly significant and the magnitude of the coefficient is barely affected, suggesting that our main result is not driven by any omitted variable. ${ }^{32}$

The first group of additional control variables contains exogenous soil characteristics, which

\footnotetext{
${ }^{30}$ Given the linearity implied by the measure of mafia activity, it takes 30 mines more to have an increase in mafia activity from one level (not present, presence is low, intermediate, high) to the next.

${ }^{31}$ Replicating the entire analysis of Table 3 using standard errors clustered at the level of departments delivers similar results, i.e. sulfur always enters with a positive and significant coefficient. A more accurate way of clustering standard errors using spatial techniques is presented later in this section.

${ }^{32}$ The coefficient on sulfur is only raised when we add land fragmentation to the controls. Yet, notice that this reduces sample size from 282 to 237 municipalities since, as discussed in the previous section, information on fragmentation are available only for 237 municipalities.
} 
Table 3: Baseline Estimates

Dependent variable: Cutrera's index of early mafia presence $\left(m a f_{\_} c\right)$

\begin{tabular}{|c|c|c|c|c|c|c|c|}
\hline & (1) & (2) & (3) & (4) & (5) & (6) & (7) \\
\hline Sulfur & $\begin{array}{c}0.0328^{* * *} \\
(0.0105)\end{array}$ & $\begin{array}{c}0.0224^{* * *} \\
(0.0082)\end{array}$ & $\begin{array}{c}0.0237^{* * *} \\
(0.0089)\end{array}$ & $\begin{array}{l}0.0228^{* *} \\
(0.0091)\end{array}$ & $\begin{array}{l}0.0234^{* *} \\
(0.0092)\end{array}$ & $\begin{array}{c}0.0239^{* * *} \\
(0.0089)\end{array}$ & $\begin{array}{c}0.0549^{* * *} \\
(0.0127)\end{array}$ \\
\hline Citrus suitability & & & $\begin{array}{c}-0.0251^{*} \\
(0.0150)\end{array}$ & $\begin{array}{l}-0.0155 \\
(0.0151)\end{array}$ & $\begin{array}{l}-0.0235 \\
(0.0163)\end{array}$ & $\begin{array}{l}-0.0227 \\
(0.0166)\end{array}$ & $\begin{array}{c}-0.0293 \\
(0.0180)\end{array}$ \\
\hline Cereals suitability & & & $\begin{array}{l}0.0235^{* *} \\
(0.0108)\end{array}$ & $\begin{array}{l}0.0223^{* *} \\
(0.0108)\end{array}$ & $\begin{array}{l}0.0224^{* *} \\
(0.0107)\end{array}$ & $\begin{array}{l}0.0224^{* *} \\
(0.0110)\end{array}$ & $\begin{array}{c}0.0296^{* * *} \\
(0.0111)\end{array}$ \\
\hline Olive suitability & & & $\begin{array}{l}-0.0037 \\
(0.0119)\end{array}$ & $\begin{array}{l}-0.0039 \\
(0.0119)\end{array}$ & $\begin{array}{c}0.0009 \\
(0.0131)\end{array}$ & $\begin{array}{c}-0.0016 \\
(0.0129)\end{array}$ & $\begin{array}{l}-0.0001 \\
(0.0145)\end{array}$ \\
\hline Water scarcity & & & $\begin{array}{c}0.1267 \\
(0.1986)\end{array}$ & $\begin{array}{l}-0.0460 \\
(0.1990)\end{array}$ & $\begin{array}{l}-0.0231 \\
(0.1923)\end{array}$ & $\begin{array}{c}0.0057 \\
(0.1933)\end{array}$ & $\begin{array}{l}-0.0548 \\
(0.2010)\end{array}$ \\
\hline Ruggedness & & & & $\begin{array}{l}-0.0011 \\
(0.0008)\end{array}$ & $\begin{array}{l}-0.0010 \\
(0.0008)\end{array}$ & $\begin{array}{l}-0.0011 \\
(0.0008)\end{array}$ & $\begin{array}{l}-0.0006 \\
(0.0009)\end{array}$ \\
\hline Diff. elevation & & & & $\begin{array}{c}0.0004^{* * *} \\
(0.0001)\end{array}$ & $\begin{array}{c}0.0004^{* * *} \\
(0.0001)\end{array}$ & $\begin{array}{c}0.0005^{* * *} \\
(0.0001)\end{array}$ & $\begin{array}{c}0.0006^{* * *} \\
(0.0002)\end{array}$ \\
\hline Postal roads & & & & & $\begin{array}{c}0.0811 \\
(0.1008)\end{array}$ & $\begin{array}{c}0.0975 \\
(0.1002)\end{array}$ & $\begin{array}{c}0.1470 \\
(0.1127)\end{array}$ \\
\hline Distance to river & & & & & $\begin{array}{c}0.0101 \\
(0.0092)\end{array}$ & $\begin{array}{c}0.0045 \\
(0.0094)\end{array}$ & $\begin{array}{c}0.0091 \\
(0.0101)\end{array}$ \\
\hline Distance to port & & & & & $\begin{array}{l}-0.0087 \\
(0.0060)\end{array}$ & $\begin{array}{l}-0.0034 \\
(0.0069)\end{array}$ & $\begin{array}{l}-0.0022 \\
(0.0080)\end{array}$ \\
\hline Urban & & & & & & $\begin{array}{c}0.1855 \\
(0.1898)\end{array}$ & $\begin{array}{c}0.0925 \\
(0.2133)\end{array}$ \\
\hline Population density & & & & & & $\begin{array}{c}0.0013^{* * *} \\
(0.0005)\end{array}$ & $\begin{array}{c}0.0012^{* *} \\
(0.0005)\end{array}$ \\
\hline Land fragmentation & & & & & & & $\begin{array}{c}0.0961 \\
(0.1315)\end{array}$ \\
\hline Department FEs & No & Yes & Yes & Yes & Yes & Yes & Yes \\
\hline Observations & 285 & 285 & 282 & 282 & 282 & 282 & 237 \\
\hline$R^{2}$ & 0.042 & 0.567 & 0.577 & 0.594 & 0.601 & 0.618 & 0.659 \\
\hline
\end{tabular}

Notes. This table presents the results of OLS estimates for Sicilian municipalities for which values for all the variables are available. The dependent variable is $m a f_{-} c$, the level of mafia activity at the end of XIX century as coded by Cutrera (1900) on a 0 to 3 scale ( 0 is no mafia activity, 3 is large mafia activity). The main explanatory variable Sulfur is the number of sulfur mines as collected by Squarzina (1963), while the other control variables are described in the main text. Department fixed effects are included in all specifications except the first. In columns 1 and 2 the number of observations is 285 , while in columns 3-7 it drops to 282 due to the fact that for 3 municipalities information for at least one of the control variables included in the regressions is missing. Robust standard errors are presented in parentheses. *,** and *** denote rejection of the null hypothesis of the coefficient being equal to 0 at $10 \%, 5 \%$ and $1 \%$ significance level, respectively. 
are related to agricultural activity: column 3 includes soil suitability for cultivation of citrus fruits, cereals and olives, as well as a dummy for water scarcity. It is important to control for such factors because many scholars have argued that mafia's emergence was related to citrus cultivation (Lupo, 1993; Gambetta, 1993; Dickie, 2004; Del Monte and Pennacchio, 2011; Dimico et al., 2012) and also to mafia's possibility to control scarce water resources and thus have high extortionary power towards agricultural production (Sylos Labini, 2003). Both suitability for cereals and for citrus have a significant effect, the former positive and the latter negative, but only the former effect remains significant as additional controls are introduced. These results do not support the widely held idea that early mafia's development was related to citrus cultivation. Column 4 adds two geographic controls: average ruggedness and difference in elevation (Nunn and Puga, 2012; Michalopoulos, 2012). Ruggedness is never significant, while difference in elevation is strongly significant and positive. Column 5 adds the presence of 1799 postal roads, as well as distance from the closest non-seasonal river and from the closest commercial port. Column 6 further adds population density in 1861 and a dummy for urban municipalities. Such variables are related to the level of economic activity, both legal and illegal (see, e.g. Glaeser and Sacerdote, 1999; Buonanno et al., 2012). In line with the literature, we find that population density is positively and significantly related to mafia's emergence. Finally, column 7 adds land fragmentation, which according to Bandiera (2003) should be relevant for mafia's emergence, but we find no support for her thesis.

A common concern in the resource curse literature is that results may be driven by outliers. To address this aspect we replicate our econometric analysis excluding the two municipalities with a disproportionately high number of sulfur mines, and, alternatively, using a robust estimator which down-weighs observations with large residuals using the Huber weight function. In both cases, the magnitude of the coefficient on sulfur increases and is estimated even more precisely, which suggests that, if anything, our results are tempered by the presence of outliers $^{33}$. As an additional robustness check, we estimate our baseline regression using instead of

\footnotetext{
${ }^{33}$ Both sets of results, not shown here, are available upon request. The two municipalities are Enna and Caltanissetta which display respectively 61 and 52 sulphur mines.
} 
the number of sulfur mines (sulfur) a dummy (sulfur_d) that equals one for those municipalities with at least one sulfur mine. Using sulfur_d is important because we do not have information on the quantity of sulfur extracted in each mine and we therefore put ourselves in the worst case scenario, that is we do not exploit at all the information on the intensive margin in the distribution of sulfur. Table 4 reproduces the same specifications of Table 3, but it substitutes sulfur $\_d$ (the dummy for the presence of at least a sulfur mine in a municipality) for sulfur. For the sake of space, we only report the coefficient of sulfur_d. Results show that, even if we neglect the information on the intensive margin of sulfur extraction and only rely on the extensive margin, the presence of sulfur is still significant to explain mafia's emergence. Yet, the slight decrease in significance levels also suggests that the intensive margin was relevant as well.

Table 4: Baseline Estimates with Sulfur Dummy

Dependent variable: Cutrera's index of early mafia presence $\left(m a f_{-} c\right)$

\begin{tabular}{lccccccc}
\hline & $(1)$ & $(2)$ & $(3)$ & $(4)$ & $(5)$ & $(6)$ & $(7)$ \\
\hline Sulfur dummy & $0.5532^{* * *}$ & 0.3594 & $0.4501^{* *}$ & $0.3968^{*}$ & $0.4165^{*}$ & $0.4916^{* *}$ & $0.4550^{* *}$ \\
& $(0.1762)$ & $(0.2193)$ & $(0.2286)$ & $(0.2370)$ & $(0.2449)$ & $(0.2237)$ & $(0.2168)$ \\
Department FEs & No & Yes & Yes & Yes & Yes & Yes & Yes \\
Suitability and water & No & No & Yes & Yes & Yes & Yes & Yes \\
Geomorphological & No & No & No & Yes & Yes & Yes & Yes \\
Distances & No & No & No & No & Yes & Yes & Yes \\
Sociodemographic & No & No & No & No & No & Yes & Yes \\
Land fragmentation & No & No & No & No & No & No & Yes \\
Observations & 285 & 285 & 282 & 282 & 282 & 282 & 237 \\
$R^{2}$ & 0.033 & 0.559 & 0.570 & 0.587 & 0.593 & 0.613 & 0.639 \\
\hline
\end{tabular}

Notes. This table presents the results of OLS estimates for Sicilian municipalities, for which values for all the variables are available. The dependent variable is $m a f_{-} c$, the level of mafia activity at the end of XIX century as coded by Cutrera (1900) on a 0 to 3 scale (0 is no mafia activity, 3 is large mafia activity). The main explanatory variable, Sulfur dummy, is a dummy taking value one if the number of sulfur mines as collected by Squarzina (1963) is greater than zero, while the other control variables are described in the main text. Department fixed effects are included in all specifications except the first. In columns 1 and 2 the number of observations is 285, while in columns 3-7 it drops to 282 due to the fact that for 3 municipalities information for at least one of the control variables included in the regressions is missing. Robust standard errors are presented in parentheses. $* * *$ and $* * *$ denote rejection of the null hypothesis of the coefficient being equal to 0 at $10 \%, 5 \%$ and $1 \%$ significance level, respectively. 
As an additional check we control for possible spatial effects. There is no reason to believe that mafia's activity follows the administrative boundaries of municipalities. Mafia lords may indeed offer protection and practice extortion in neighbouring municipalities, whose territory they control. They may also establish agreements with other mafia lords, who control different territories, for instance to grant protection to their clients' goods transiting through them. Moreover, protection externalities may foster mafia's activity in a municipality just because the mafia is active in neighbouring municipalities. There may therefore be relevant spatial spillovers from a municipality to its neighbours. Omitting to take them into account may reduce the efficiency of our estimates and bias them.

To address this issue, we estimate a spatial model by means of the generalised spatial two stage least squares (GS2SLS) estimator of Kelejian and Prucha (1998). Results are presented in table 5, which reproduces the same specification of column 6 of Table 3 in Panel A (i.e. using sulfur as explanatory variable) and the same specification of column 6 of Table 4 in Panel B (i.e. using sulfur dummy as explanatory variable). We employ both a non-standardised (columns 1 to 3 ) and a row-standardised (columns 4 to 6) contiguity matrix. We implement a spatial error model (columns 1 and 4), a spatial autoregressive model (columns 2 and 5) and a model that combines the two by considering both a spatial lag and a spatial error structure (columns 3 and $6)$.

Allowing for a spatial structure in our data does not alter our baseline estimates: independently of how we specify the spatial model, the coefficient of sulfur (and sulfur dummy) is extremely stable in magnitude and is always highly significant. While the coefficients on the spatial structure do not show a stable and consistent pattern across specifications, they are often significant when using the row-standardised contiguity matrix, suggesting that mafia's activity in neighbouring municipalities might indeed be relevant and thus spatial estimates are justified. Looking at the full model reported in column 6, in both Panels the positive coefficient on the spatial error is in line with intuition, while the negative coefficient of the spatial lag is consistent with mafia families endogenously locating at a sufficiently large distance from other families. 
Table 5: Spatial Estimates

Dependent variable: Cutrera's index of early mafia presence $\left(m a f_{\_} c\right)$

\begin{tabular}{|c|c|c|c|c|c|c|}
\hline & (1) & (2) & (3) & (4) & (5) & (6) \\
\hline \multicolumn{7}{|c|}{ Panel A } \\
\hline Sulfur & $\begin{array}{c}0.0229^{* * *} \\
(0.0072)\end{array}$ & $\begin{array}{c}0.0230^{* * *} \\
(0.0071)\end{array}$ & $\begin{array}{c}0.0227^{* * *} \\
(0.0072)\end{array}$ & $\begin{array}{c}0.0211^{* * *} \\
(0.0071)\end{array}$ & $\begin{array}{c}0.0227^{* * *} \\
(0.0071)\end{array}$ & $\begin{array}{c}0.0231^{* * *} \\
(0.0066)\end{array}$ \\
\hline$\lambda$ & $\begin{array}{l}0.0062 \\
(0.010)\end{array}$ & & $\begin{array}{l}0.0043 \\
(0.010)\end{array}$ & $\begin{array}{c}0.4337^{\text {*** }} \\
(0.131)\end{array}$ & & $\begin{array}{c}0.5776^{* * *} \\
(0.115)\end{array}$ \\
\hline$\rho$ & & $\begin{array}{l}0.0257 \\
(0.022)\end{array}$ & $\begin{array}{l}0.0188 \\
(0.025)\end{array}$ & & $\begin{array}{l}0.1151 \\
(0.102)\end{array}$ & $\begin{array}{c}-0.4495^{* * *} \\
(0.149)\end{array}$ \\
\hline Controls & Yes & Yes & Yes & Yes & Yes & Yes \\
\hline Observations & 280 & 280 & 280 & 280 & 280 & 280 \\
\hline \multicolumn{7}{|c|}{ Panel B } \\
\hline Sulfur dummy & $\begin{array}{c}0.4680^{* * *} \\
(0.1811)\end{array}$ & $\begin{array}{c}0.4774^{* * *} \\
(0.1807)\end{array}$ & $\begin{array}{l}0.4654^{* *} \\
(0.1816)\end{array}$ & $\begin{array}{c}0.4417^{* *} \\
(0.1791)\end{array}$ & $\begin{array}{c}0.4618^{* * *} \\
(0.1798)\end{array}$ & $\begin{array}{c}0.4896^{\text {*** }} \\
(0.1694)\end{array}$ \\
\hline$\lambda$ & $\begin{array}{l}0.0103 \\
(0.010)\end{array}$ & & $\begin{array}{l}0.0084 \\
(0.010)\end{array}$ & $\begin{array}{c}0.4082^{* * *} \\
(0.135)\end{array}$ & & $\begin{array}{c}0.5326^{* * *} \\
(0.122)\end{array}$ \\
\hline$\rho$ & & $\begin{array}{l}0.0304 \\
(0.021)\end{array}$ & $\begin{array}{l}0.0175 \\
(0.025)\end{array}$ & & $\begin{array}{l}0.1254 \\
(0.099)\end{array}$ & $\begin{array}{c}-0.3848^{* *} \\
(0.153)\end{array}$ \\
\hline Controls & Yes & Yes & Yes & Yes & Yes & Yes \\
\hline Observations & 280 & 280 & 280 & 280 & 280 & 280 \\
\hline
\end{tabular}

Notes. This table presents the results of a spatial model estimated by means of the generalised spatial two stage least squares (GS2SLS) estimator of Kelejian and Prucha (1998). Included controls are the same as in the specification of column 6 of table 3 . Columns 1 to 3 employ a non-standardised contiguity matrix, while a row-standardised one is used in columns 4 to 6. A Spatial Error model, a Spatial Autoregressive model and a model that combines the two by considering both a spatial lag and a spatial error structure are respectively presented in columns 1 and 4 , columns 2 and 5 and columns 3 and 6. $\lambda$ is the spatial error term, while $\rho$ is the spatial lag. The dependent variable is maf_c the level of mafia activity at the end of XIX century as coded by Cutrera (1900) on a 0 to 3 scale ( 0 is no mafia activity, 3 is large mafia activity). The main explanatory variable in Panel A, Sulfur, is the number of sulfur mines as collected by Squarzina (1963), while the other control variables are described in the main text (excluding the fragmentation index). In Panel $\mathrm{B}$, the main explanatory variable is a dummy taking value one when Sulfur is positive. Department fixed effects are included in all specifications. Robust standard errors are presented in parentheses. *,** and *** denote rejection of the null hypothesis of the coefficient being equal to 0 at $10 \%, 5 \%$ and $1 \%$ significance level, respectively. 


\subsection{District-level Estimates}

In our baseline regressions we used our preferred measure of mafia intensity, maf_c, which is available at the municipality level. In order to obtain estimates directly comparable with other studies (Bandiera, 2003; Pazzona, 2010; Dimico et al., 2012), we employ the mafia measure as defined in the Damiani-Jacini parliamentary inquiry, $m a f_{-} d$, which is only available at district level, for 158 Sicilian districts.

We replicate the analysis proposed in our baseline regression, presented in Table 3, with the same specification, but substituting $m a f_{-} d$ for $m a f_{-} c$. Since estimates exploit district-level information on mafia's activity, we correspondingly re-define all our regressors at this level of geographical and administrative aggregation. District-level findings are presented in Table 6. Throughout all regressions, the estimated coefficient on sulfur is strongly significant and is extremely stable, suggesting that our results are not driven by either the specific mafia measure used or by any omitted variable.

As previously stated, the use of maf $d$ is not only useful as a robustness check, but it also allows a more direct comparison with other contributions. In particular, Bandiera (2003), who also uses district-level data, provides early evidence, based on 70 districts located in the western part of Sicily, supporting the idea that land fragmentation may have favored mafia's emergence; while on the contrary Pazzona (2010) provides evidence that the origins of the Sicilian mafia are rooted in the presence of large landholdings. Our results, both those based on all the 158 available districts, as well as those presented in Table 3, based on 237 municipalities, do not support their arguments.

\subsection{Neighbour-pair Fixed Effects}

So far we have presented consistent and robust findings, documenting the significant effect of the presence of sulfur on mafia's origins. Since sulfur is not randomly distributed across Sicily, but rather geographically concentrated, we have relied on department fixed effects and on municipality-level controls to make sure that differences in sulfur endowment do not pick 
Table 6: District-level Estimates

Dependent variable: Damiani-Jacini's index of early mafia presence $\left(m a f_{-} d\right.$ )

\begin{tabular}{|c|c|c|c|c|c|c|c|}
\hline & (1) & (2) & (3) & (4) & (5) & (6) & (7) \\
\hline Sulfur & $\begin{array}{c}0.0354^{* * *} \\
(0.0080)\end{array}$ & $\begin{array}{c}0.0318^{* * *} \\
(0.0115)\end{array}$ & $\begin{array}{c}0.0325^{* * *} \\
(0.0116)\end{array}$ & $\begin{array}{c}0.0327^{* * *} \\
(0.0117)\end{array}$ & $\begin{array}{c}0.0326^{* * *} \\
(0.0121)\end{array}$ & $\begin{array}{c}0.0347^{* * *} \\
(0.0122)\end{array}$ & $\begin{array}{l}0.0322^{* *} \\
(0.0127)\end{array}$ \\
\hline Citrus suitability & & & $\begin{array}{c}0.0413 \\
(0.0315)\end{array}$ & $\begin{array}{c}0.0483 \\
(0.0324)\end{array}$ & $\begin{array}{c}0.0444 \\
(0.0344)\end{array}$ & $\begin{array}{c}0.0399 \\
(0.0351)\end{array}$ & $\begin{array}{c}0.0378 \\
(0.0352)\end{array}$ \\
\hline Cereals suitability & & & $\begin{array}{l}-0.0034 \\
(0.0193)\end{array}$ & $\begin{array}{c}0.0024 \\
(0.0188)\end{array}$ & $\begin{array}{c}0.0022 \\
(0.0196)\end{array}$ & $\begin{array}{c}0.0042 \\
(0.0197)\end{array}$ & $\begin{array}{c}0.0016 \\
(0.0201)\end{array}$ \\
\hline Olive suitability & & & $\begin{array}{l}-0.0203 \\
(0.0180)\end{array}$ & $\begin{array}{l}-0.0203 \\
(0.0177)\end{array}$ & $\begin{array}{l}-0.0212 \\
(0.0198)\end{array}$ & $\begin{array}{l}-0.0207 \\
(0.0199)\end{array}$ & $\begin{array}{l}-0.0155 \\
(0.0210)\end{array}$ \\
\hline Water Scarcity & & & $\begin{array}{l}0.2763^{*} \\
(0.1678)\end{array}$ & $\begin{array}{c}0.2842 \\
(0.1730)\end{array}$ & $\begin{array}{c}0.2669 \\
(0.1711)\end{array}$ & $\begin{array}{c}0.2365 \\
(0.1720)\end{array}$ & $\begin{array}{c}0.2078 \\
(0.1820)\end{array}$ \\
\hline Ruggedness & & & & $\begin{array}{c}0.9873 \\
(2.1534)\end{array}$ & $\begin{array}{c}1.2538 \\
(2.2252)\end{array}$ & $\begin{array}{c}0.9421 \\
(2.2031)\end{array}$ & $\begin{array}{c}0.6733 \\
(2.1898)\end{array}$ \\
\hline Diff. elevation & & & & $\begin{array}{c}0.0002 \\
(0.0002)\end{array}$ & $\begin{array}{c}0.0002 \\
(0.0002)\end{array}$ & $\begin{array}{c}0.0003 \\
(0.0002)\end{array}$ & $\begin{array}{c}0.0003 \\
(0.0002)\end{array}$ \\
\hline Postal roads & & & & & $\begin{array}{c}0.2210 \\
(0.1906)\end{array}$ & $\begin{array}{c}0.2877 \\
(0.1947)\end{array}$ & $\begin{array}{c}0.2680 \\
(0.1993)\end{array}$ \\
\hline Distance to river & & & & & $\begin{array}{c}0.0026 \\
(0.0177)\end{array}$ & $\begin{array}{l}-0.0022 \\
(0.0182)\end{array}$ & $\begin{array}{c}-0.0040 \\
(0.0184)\end{array}$ \\
\hline Distance to port & & & & & $\begin{array}{l}-0.0009 \\
(0.0126)\end{array}$ & $\begin{array}{c}0.0016 \\
(0.0145)\end{array}$ & $\begin{array}{c}0.0002 \\
(0.0144)\end{array}$ \\
\hline Urban & & & & & & $\begin{array}{l}-0.1216 \\
(0.4075)\end{array}$ & $\begin{array}{l}-0.1115 \\
(0.4097)\end{array}$ \\
\hline Population density & & & & & & $\begin{array}{l}0.0014^{*} \\
(0.0008)\end{array}$ & $\begin{array}{c}0.0014^{*} \\
(0.0008)\end{array}$ \\
\hline Land fragmentation & & & & & & & $\begin{array}{l}-0.1847 \\
(0.2467)\end{array}$ \\
\hline Department FEs & No & Yes & Yes & Yes & Yes & Yes & Yes \\
\hline Observations & 158 & 158 & 158 & 158 & 158 & 158 & 158 \\
\hline$R^{2}$ & 0.105 & 0.232 & 0.249 & 0.259 & 0.266 & 0.283 & 0.288 \\
\hline
\end{tabular}

Notes. This table presents the results of OLS estimates for Sicilian districts for which values for all the variables are included. The dependent variable is $m a f d$, the level of mafia activity around 1883 as coded by Damiani (1885) on a 0 to 3 scale (0 is no mafia activity, 3 is large mafia activity). The main explanatory variable Sulfur is the number of sulfur mines as collected by Squarzina (1963), while the other control variables are described in the main text. Department fixed effects are included in all specifications except the first. Robust standard errors are presented in parentheses. *, ** and $* * *$ denote rejection of the null hypothesis of the coefficient being equal to 0 at $10 \%, 5 \%$ and $1 \%$ significance level, respectively. 
up the effects of some other characteristics, which may be relevant for mafia's emergence. In this section we go even deeper and, rather than comparing municipalities with different sulfur endowments within a given department, we follow Acemoglu et al. (2012) and exploit variations in sulfur endowments across direct neighbours.

In particular, we restrict our analysis to the 48 municipalities which have sulfur mines and the 54 municipalities without sulfur mines which are adjacent to them. ${ }^{34}$ As in Acemoglu et al. (2012), we implement the neighbour-pair fixed effects estimator, very similar to a matching methodology and to a regression discontinuity design, comparing each sulfur-mining municipality to each of its direct neighbours without sulfur. Figure 4 visually presents municipalities with sulfur mines and their neighbours.

This empirical strategy makes it possible to directly control for unobservables that are common across adjacent municipalities by including neighbour-pair fixed effects. Indeed, we rely on the assumption that adjacent municipalities faced similar institutional and contextual conditions (i.e. law enforcement, state presence, culture, labour market, geography), and are likely to be very similar across any other unobservables. Within the neighbour pair, we claim that the exogenous source of variation in mafia's activity is the presence of sulfur mines.

Formally, we define with $S$ the subset of municipalities with sulfur mines and with $N(s)$ all the adjacent municipalities without sulfur mines of each element of $S$. We use $s$ and $i$ to index municipalities with and without sulfur mines, respectively. We estimate the following model by means of OLS:

$$
\begin{gathered}
\text { maf_c }_{s}=\beta \text { sulfur } \\
s+\gamma X_{s}^{\prime}+\psi_{s i}+\nu_{s} \quad s \in S \\
\text { maf_c }_{i}=\beta \text { sulfur }_{i}+\gamma X_{i}^{\prime}+\psi_{s i}+\nu_{i} \quad i \in N(s)
\end{gathered}
$$

where $X_{t}^{\prime}$ collects municipality-level controls, $\psi_{s i}$ represents common unobservables for the neighbour pair $(s, i)$ and $\nu_{t}$ represents municipality-specific unobservables $(t=s, i)$. Neighbour-

\footnotetext{
${ }^{34}$ Note that although 48 municipalities have sulfur mines, 13 of them have as only neighbours other municipalities with sulfur, so they cannot be exploited in this analysis.
} 


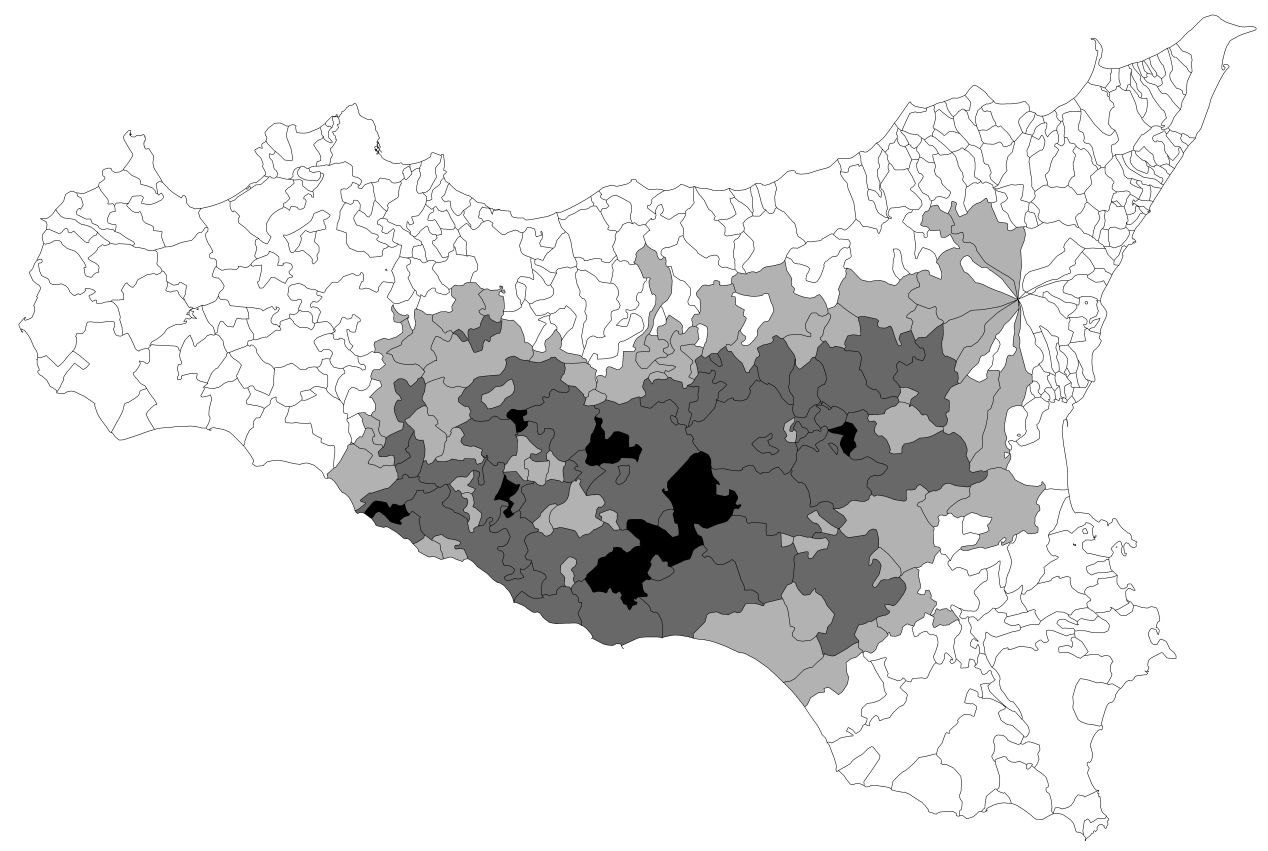

Fig. 4: Municipalities with Sulfur Mines and their Neighbours

Notes. White municipalities are excluded from the analysis because both them and their neighbours do not host sulfur. Light grey municipalities are those 54 without sulfur that have neighbouring municipalities with sulfur (the 35 in dark grey). Black municipalities are excluded because, even if endowed with sulfur, they do not neighbour any non-sulfur municipality. 
pair fixed effects estimates are presented in Table 7. For simplicity we only present the coefficient on sulfur, but consistently with Table 3 we progressively add all the controls described in the previous section. The coefficient of sulfur in the neighbour-pair fixed effects estimates is always significant and its magnitude is very close to our baseline findings, providing additional and compelling evidence on the role played by sulfur endowment in mafia's emergence.

Table 7: Neighbour-pair Fixed Effect Estimates

Dependent variable: Cutrera's index of early mafia presence $\left(m a f \_c\right)$

\begin{tabular}{lcccccc}
\hline & $(1)$ & $(2)$ & $(3)$ & $(4)$ & $(5)$ & $(6)$ \\
\hline Sulfur & $0.0206^{* * *}$ & $0.0172^{* *}$ & $0.0231^{* *}$ & $0.0216^{* *}$ & $0.0196^{* *}$ & $0.0207^{* * *}$ \\
Neighbour-pair FEs & $(0.0061)$ & $(0.0073)$ & $(0.0093)$ & $(0.0094)$ & $(0.0094)$ & $(0.0055)$ \\
Suitability and water & No & Yes & Yes & Yes & Yes & Yes \\
Geomorphological & No & No & Yes & Yes & Yes & Yes \\
Distances & No & No & No & Yes & Yes & Yes \\
Sociodemographic & No & No & No & No & Yes & Yes \\
Observations & 162 & 162 & 162 & 162 & 162 & Yes \\
$R^{2}$ & 0.054 & 0.637 & 0.667 & 0.672 & 0.681 & 0.795 \\
\hline
\end{tabular}

Notes. This table presents the results of OLS estimates for Sicilian municipalities for which values for all the variables are available. Observations are all those municipalities that form a couple in which a municipality has sulfur and its neighbour has not. Each municipality in a pair shares a common pair fixed effect. The dependent variable is $m a f_{-} c$, the level of mafia activity at the end of XIX century as coded by Cutrera (1900) on a 0 to 3 scale (0 is no mafia activity, 3 is large mafia activity). The main explanatory variable Sulfur is the number of sulfur mines as collected by Squarzina (1963), while the other control variables are described in the main text. Neighbour pair fixed effects are included in all specifications except the first. Robust standard errors are presented in parentheses. *,** and *** denote rejection of the null hypothesis of the coefficient being equal to 0 at $10 \%, 5 \%$ and $1 \%$ significance level, respectively.

\subsection{Mafia's Persistence}

Although the main purpose of our research is to shed light on the historical determinants of mafia's emergence, we are also interested in understanding to what extent these factors have had persistent effect on the presence of the mafia today. In particular, we analyze whether the incidence of mafia activities today is correlated with the presence of the mafia in the early stages of its development. In order to pursue our goal we measure today's mafia intensity by means of 
several variables available at the municipality level: (i) dissolution of municipal administration due to mafia infiltrations; (ii) seized firms and (iii) seized real estate properties. We define a dummy that takes value one if the municipality council was dissolved due to mafia infiltration over the period 1991 to 2011 (source: Ministero dell'Interno) and two dummies equal to one, respectively, if at least a firm and at least a real estate/property have been seized by the Italian judicial authority in the municipality by the end of 2011 (source: Agenzia del Demanio). ${ }^{35}$ It is worth noticing that over the considered period more than $10 \%$ of Sicilian municipalities were dissolved and firms and real estate properties were seized in more than $23 \%$ and $44 \%$ of Sicilian municipalities, respectively. Moreover, we also consider non-mafia related crime rates per 100,000 inhabitants at the municipality level as a falsification test (source: Polizia di Stato, Ministero dell'Interno). Indeed, we might expect that, given the strict territorial control exerted by the Sicilian mafia, property crime should be unaffected or even lowered in municipalities with a stronger presence of mafia. We propose a simple instrumental variable approach in which we regress current days mafia (and other crime rates) on instrumented historical mafia. In particular, the first stage is the specification presented in column 2 of Table 3 (i.e. maf_c regressed on sulfur and department fixed effects) and the second stage is a measure of crime today regressed on the instrumented measure of historical mafia (i.e., maf_c). Instrumental variable estimates, presented in Table 8 , show a strong effect of early mafia on today's mafia presence, confirming the persistence of the phenomenon over time. Moreover, other crime rates (i.e., theft, burglary, car theft and robbery) are in some cases negatively affected by mafia's historical presence, suggesting that mafia's territorial and social control acts as a deterrent of non-mafia-related crimes.

\footnotetext{
${ }^{35}$ Law n. 221 (July 1991) sets the rule for council dissolution due to mafia infiltration. Law n. 646 (September 1982), known as Law "Rognoni - La Torre" rules the seizure of firms and real estate properties belonging to mafia-like organizations.
} 
Table 8: Persistence

\begin{tabular}{cccccccc}
\hline & Council & Real estates & Firms & Theft & Burglary & Car theft & Robbery \\
\cline { 2 - 7 } & $(1)$ & $(2)$ & $(3)$ & $(4)$ & $(5)$ & $(6)$ & $(7)$ \\
maf_c & $0.0706^{* * *}$ & $0.1477^{* * *}$ & $0.1524^{* * *}$ & $-183.9049^{* * *}$ & 3.1591 & $-28.3848^{* * *}$ & -2.2930 \\
\multirow{2}{*}{ Observations } & $(0.0187)$ & $(0.0325)$ & $(0.0277)$ & $(52.9439)$ & $(10.1428)$ & $(9.4874)$ & $(2.0695)$ \\
& 282 & 282 & 282 & 282 & 282 & 282 & 282 \\
\hline
\end{tabular}

Notes. This table present the result of instrumental variable estimates in which the first stage is specification presented in column 2 of table 3 (i.e. maf_c regressed on sulfur and department fixed effects) and the second stage is a measure of crime today on the instrumented measure of historical mafia (i.e., maf_c). Today mafia presence is measured by: (i) dissolution of municipal administration due to mafia infiltrations; (ii) seized firms and (iii) seized real estate properties. Council is a dummy that takes value one whether the municipality council dissolved due to mafia infiltration over the period 1991 to 2011 (source: Ministero dell'Interno), Real estates is a dummy equals to one whether at least a real estate property has been seized by the Italian judicial authority and Firms is a dummy equals to 1 whether at least a firm has been seized (source: Agenzia del Demanio). Theft, Burglary, Car theft and Robbery are crime rates per 100,000 inhabitants for each Sicilian municipality (source: Polizia di Stato, Ministero dell'Interno). Robust standard errors are presented in parentheses. $*, * *$ and $* * *$ denote rejection of the null hypothesis of the coefficient being equal to 0 at $10 \%, 5 \%$ and $1 \%$ significance level, respectively.

\section{Conclusions}

Under weak institutions, a boom in the value of natural resources may raise both the demand for private protection and the opportunities for rent appropriation through extortion, thus favoring the emergence of mafia-type organizations, since they have a competitive advantage in such activities, and thus translating in a resource curse with potentially persistent consequences. We empirically investigate the validity of this argument for the specific case of the origins of the Sicilian mafia, which emerged in the mid XIX century, when the widespread power vacuum created by the collapse of the Bourbon Kingdom coincided with the soaring international demand for Sicilian sulfur. Our evidence, based on a newly collected municipality-level dataset, shows a significant and robust effect of sulfur endowments on early mafia activity. We claim this effect to be causal, since sulfur is exogenously distributed as any natural resource, it is easily discoverable in Sicily since it is mainly superficial, and until the beginning of XIX it was commercially barely useless. Our findings are robust to the inclusion of several controls, including fixed effects for small areas, to the use of mafia measures at different aggregation lev- 
els, allowing for a well defined spatial structure of the data and even to the inclusion, in a RDD fashion, of fixed effects for pairs of adjacent municipalities, with and without sulfur mines.

In addition to documenting the causal effect of sulfur endowments on the origins of the Sicilian mafia, we review and further test the effect of alternative factors that have been proposed as possible determinants of the emergence of the mafia, and show that, when appropriately accounting for local fixed effects and other municipal controls, none of them appear to display an empirically robust effect.

University of Bergamo

Sciences Po

University of Bologna

University of Bologna

Submitted: 23 April 2013

Accepted: 22 September 2014

Additional Supporting Information may be found in the online version of this article:

Appendix. Role of Citrus Cultivation. 


\section{References}

Acemoglu, D., García-Jimeno, C. and Robinson, J.A. (2012). 'Finding eldorado: slavery and long-run development in colombia', Journal of Comparative Economics, vol. 40(4), pp. 534564.

Acemoglu, D., Johnson, S. and Robinson, J. (2001). 'The colonial origins of comparative development: an empirical investigation', American Economic Review, pp. 1369-1401.

Bandiera, O. (2003). 'Land reform, the market for protection, and the origins of the sicilian mafia: theory and evidence', Journal of Law, Economics, and Organization, vol. 19(1), p. 218.

Blok, A. (1966). 'Land reform in a west sicilian latifondo village: the persistence of a feudal structure', Anthropological Quarterly, vol. 39(1), pp. 1-16.

Blok, A. (1969). 'Peasants, patrons, and brokers in western sicily', Anthropological Quarterly, vol. 42(3), pp. 155-170.

Buonanno, P., Pasini, G. and Vanin, P. (2012). 'Crime and social sanction', Papers in Regional Science, vol. 91(1), pp. 193-218.

Cabrales, A. and Hauk, E. (2011). 'The quality of political institutions and the curse of natural resources', Economic Journal, vol. 121(551), pp. 58-88.

Cancila, O. (1995). Storia dell'industria in Sicilia, Laterza.

Candeloro, G. (1956). Storia dell'Italia moderna, Feltrinelli.

Cary, J. (1799). A new map of Italy, including the islands of Sicily, Sardinia and Corsica with the post roads from the latest authorities, Cary Engraver and Map-seller.

Caselli, F. and Michaels, G. (2013). 'Do oil windfalls improve living standards? Evidence from Brazil', American Economic Journal: Applied Economics, vol. 5(1), pp. 208-38.

Collier, P. and Hoeffler, A. (2002). 'On the incidence of civil war in africa', Journal of Conflict Resolution, vol. 46(1), pp. 13-28.

Cutrera, A. (1900). La mafia e i Mafiosi, Reber, Palermo.

Dal Bó, E. and Dal Bó, P. (2011). 'Workers, warriors, and criminals: social conflict in general equilibrium', Journal of the European Economic Association, vol. 9(4), pp. 646-677. 
Damiani, A. (1885). 'Relazione del Commissario Abele Damiani, Deputato al Parlamento, sulla Prima Circoscrizione (Provincie di Caltanissetta, Catania, Girgenti, Messina, Palermo, Siracusa e Trapani', in (S. Jacini, ed.), Atti della Giunta per la Inchiesta Agraria e sulle Condizioni della Classe Agricola., Forzani e C., Tipografi del Senato, anastatic reprint by Arnaldo Forni Editore in 1987.

Del Monte, A. and Pennacchio, L. (2011). 'The structure of agricultural production and the causes of brigandage and criminal organisations in italy after unification: theory and evidence', MPRA Paper \#38875.

Dickie, J. (2004). Cosa Nostra. A history of the Sicilian Mafia, Palgrave Macmillan, New York.

Dimico, A., Isopi, A. and Olsson, O. (2012). 'Origins of the sicilian mafia: the market for lemons', Göteborg University Working Paper in Economics \#532.

Dube, O. and Vargas, J.F. (2013). 'Commodity price shocks and civil conflict: evidence from Colombia', Review of Economic Studies, vol. 80(4), pp. 1384-1421.

Durante, R. (2009). 'Risk, cooperation and the economic origins of social trust: an empirical investigation', Working paper.

Easterly, W. and Levine, R. (2003). 'Tropics, germs, and crops: how endowments influence economic development', Journal of monetary economics, vol. 50(1), pp. 3-39.

Fiorentini, G. and Peltzman, S. (1997). The economics of organised crime, Cambridge University Press.

Franchetti, L. and Sonnino, S. (1877). La Sicilia nel 1876, G. Barbera.

Frankel, J.A. (2010). ‘The natural resource curse: a survey’, NBER Working Paper \#15836.

Galor, O. and Weil, D. (2000). 'Population, technology, and growth: from Malthusian stagnation to the demographic transition and beyond', American Economic Review, pp. 806-828.

Gambetta, D. (1993). The Sicilian Mafia: the business of private protection, Harvard University Press.

Glaeser, E.L. and Sacerdote, B. (1999). 'Why is there more crime in cities?', Journal of Political Economy, vol. 107(S6), pp. S225-S258.

Glaeser, E.L., Sacerdote, B. and Scheinkman, J.A. (1996). 'Crime and social interactions', Quarterly Journal of Economics, vol. 111(2), pp. 507-48. 
Grigg, D. (1995). An introduction to agricultural geography, Routledge.

Haber, S. and Menaldo, V. (2011). 'Do natural resources fuel authoritarianism ? a reappraisal of the resource curse', American Political Science Review, vol. 105(1), pp. 1-26.

Jennings, W.P. (1984). 'A note on the economics of organized crime', Eastern Economic Journal, vol. 10(3), pp. 315-321.

Kelejian, H.H. and Prucha, I.R. (1998). 'A generalized spatial two-stage least squares procedure for estimating a spatial autoregressive model with autoregressive disturbances', Journal of Real Estate Finance and Economics, vol. 17(1), pp. 99-121.

Konrad, K. and Skaperdas, S. (2012). 'The market for protection and the origin of the state', Economic Theory, vol. 50, pp. 417-443.

Kutney, G. (2009). Sulfur: history, technology, applications and industry, Elsevier Science.

Landes, D.S. (1998). The wealth and poverty of nations: Why some are so rich and some so poor, WW Norton \& Company.

Lupo, S. (1993). Storia della mafia dalle origini ai nostri giorni, Donzelli, Roma.

Mastrobuoni, G. and Patacchini, E. (2012). 'Organized crime networks: an application of network analysis techniques to the american mafia', Review of Network Economics, vol. 11(3).

Mehlum, H., Moene, K. and Torvik, R. (2006a). 'Cursed by resources or institutions?', The World Economy, vol. 29(8), pp. 1117-1131.

Mehlum, H., Moene, K. and Torvik, R. (2006b). 'Institutions and the resource curse', Economic Journal, vol. 116(508), pp. 1-20.

Michalopoulos, S. (2012). 'The origins of ethnolinguistic diversity', American Economic Review, vol. 102(4), p. 15081539.

Michalopoulos, S., Naghavi, A. and Prarolo, G. (2012). 'Trade and geography in the origins and spread of islam', NBER Working Paper 18438.

Naritomi, J., Soares, R.R. and Assunao, J.J. (2012). 'Institutional development and colonial heritage within brazil', Journal of Economic History, vol. 72(02), pp. 393-422.

Nunn, N. and Puga, D. (2012). 'Ruggedness: The blessing of bad geography in africa', Review of Economics and Statistics, vol. 94(1), pp. 20-36. 
Nunn, N. and Qian, N. (2011). 'The potato's contribution to population and urbanization: Evidence from a historical experiment', Quarterly Journal of Economics, vol. 126(2), pp. 593650 .

Pazzona, M. (2010). 'Emerging classes and the fight for resources: an empirical investigation into the origins of the sicilian mafia', Working paper.

Pescosolido, G. (2010). 'L'economia siciliana nell'unificazione italiana', Mediterranea, vol. 19, pp. 217-234.

Petino, A. (1958). I prezzi di alcuni prodotti agricoli sui mercati di Palermo e Catania dal 1801 al 1890, Archivio Economico dell'Unificazione, Roma.

Pinotti, P. (forthcoming). 'The economic cost of organized crime: Evidence from southern italy', Economic Journal.

Rawson, W.R. (1840). 'On the sulphur trade of sicily, and the commercial relations between that country and great britain', Journal of the Statistical Society of London, vol. 2(6), pp. 446-457.

Sachs, J. and Malaney, P. (2002). 'The economic and social burden of malaria', Nature, vol. 415(6872), pp. 680-685.

Sachs, J.D. and Warner, A.M. (1995). 'Natural resource abundance and economic growth', NBER Working Paper 5398.

Sachs, J.D. and Warner, A.M. (2001). 'The curse of natural resources', European Economic Review, vol. 45(4-6), pp. 827-838.

Skaperdas, S. (2001). 'The political economy of organized crime: providing protection when the state does not', Economics of Governance, vol. 2(3), pp. 173-202.

Skaperdas, S. (2002). 'Warlord competition', Journal of Peace Research, vol. 39(4), pp. 435446.

Skaperdas, S. (2011). 'The costs of organized violence: a review of the evidence', Economics of Governance, vol. 12(1), pp. 1-23.

Sokoloff, K.L. and Engerman, S.L. (2000). 'History Lessons: Institutions, Factors Endowments, and Paths of Development in the New World', Journal of Economic Perspectives, pp. 217232. 
Squarzina, F. (1963). Produzione e Commercio dello Zolfo in Sicilia nel Secolo XIX, Industria Libraria Tipografica Editrice, Torino.

Sylos Labini, P. (2003). 'Le radici della mafia in sicilia', in (P. Sylos Labini and G. Arena, eds.), Scritti sul mezzogiorno (1954-2001), Piero Lacaita Editore, Manduria-Bari-Roma.

Varese, F. (2005). The Russian Mafia: private protection in a new market economy, Oxford University Press, USA.

Voth, H.J. and Drelichman, M. (2008). 'Institutions and the resource curse in early modern spain', in (E. Helpman, ed.), Institutions and Economic Performance, Harvard University Press. 